\title{
Early-season Extension Using June-bearing 'Chandler' Strawberry in High-elevation High Tunnels
}

\author{
Daniel Rowley, Brent L. Black ${ }^{1}$, and Dan Drost \\ Plants, Soils and Climate Department, Utah State University, 4820 Old Main \\ Hill, Logan, UT 84322-4820
}

\author{
Dillon Feuz \\ Department of Applied Economics, Utah State University, Logan, UT 84322- \\ 3530
}

Additional index words. Fragaria $\times$ ananassa, protected cultivation

\begin{abstract}
High tunnels have been used successfully in many areas of the world to extend the growing season for numerous crops. However, very little research has been conducted to evaluate the season extension benefits offered by high tunnels for small fruit crops in high-elevation growing areas such as the Intermountain West region of the United States. The use of high tunnels was investigated in North Logan, UT (lat. $41.766 \mathrm{~N}$, elev. $1405 \mathrm{~m}, 119$ freeze-free days) to extend the growing season for June-bearing strawberries. Growing systems included a fall-planted annual hill system and vertical growing systems in two different orientations. Optimum planting date for each system was determined by transplanting 'Chandler' plugs at 2-week intervals over 10 weeks. For the second year of the study, a field planting was also included. Over two seasons, the optimum planting dates were approximately the first week of September. The vertical systems were more susceptible to winter injury likely resulting from the temperature extremes in the root zone. Where winter injury was prevented, the vertical systems had higher yields per tunnel area than the in-ground system, but yield increases did not compensate for higher construction and management costs. The production window for the in-ground high tunnel planting was $\approx 4$ weeks earlier than the field-grown plants and increased profitability by $\$ 13 / \mathrm{m}^{2}$ of tunnel area.
\end{abstract}

The fresh market strawberry industry in the United States is dominated by production regions in California and Florida, where ideal growing conditions exist for long seasons (Sjulin, 2003). Ideal conditions for strawberries occur when temperatures are between 20 and $26^{\circ} \mathrm{C}$. Suboptimal temperatures (less than $20^{\circ} \mathrm{C}$ ) slow the growth and development of both the strawberry plant and fruit, whereas superoptimal temperatures above $35^{\circ} \mathrm{C}$ cause the strawberry plant to stop growing (Galletta and Bringhurst, 1990). Coastal regions in southern California provide these conditions from spring to fall, and central Florida has mild conditions throughout the winter. De-

Received for publication 23 June 2010. Accepted for publication 3 Aug. 2010.

We gratefully acknowledge the technical assistance of James Frisby. Funding was provided by grants from the Western Sustainable Agriculture Research and Education (SARE) program and the Utah Dept. of Agriculture and Food-Specialty Crop Block Grant program and from the Utah Agricultural Experiment Station-Utah State University (journal paper number 8214).

This article is a portion of a M.S. thesis submitted by D. Rowley.

Use of trade names does not imply an endorsement of the products named or criticism of similar ones not named.

${ }^{1}$ To whom reprint requests should be addressed; e-mail brent.black@usu.edu. spite a lack of ideal growing conditions, small-scale strawberry production continues throughout North America, particularly in proximity to urban centers where fresh local produce commands premium prices. This local demand has recently been increasing as a result of the expanding local food movement.

Conditions in the high-elevation valleys of the Intermountain West region of the United States are particularly challenging for strawberry production. Early spring temperatures are suboptimal, transitioning rapidly to summer temperatures that are typically superoptimal (Moller and Gillies, 2008). Wide diurnal temperature fluctuations in early spring also limit strawberry production in the region. The production window for June-bearing strawberries also coincides with peak national production and depressed wholesale prices (Pollack and Perez, 2008). The short growing season and depressed prices often make strawberry production in the Intermountain West only marginally profitable. The use of high tunnels offers an alternative approach. High tunnels have been successfully used to manipulate temperature and extend the growing season for many crops, including flowers (Rasmussen and White, 2006), vegetables (Orzolek et al., 2006), and small fruits, including strawberries (Demchak, 2009; Demchak et al., 2006). By extending the growing season earlier into the spring, direct market- oriented producers are better able to attract new customers, maintain current customers, and take advantage of higher out-of-season prices.

June-bearing strawberries in an annual hill production system are particularly efficient for maximizing early-season yields (Sjulin, 2003). This annual system has since been adapted to colder climates (Black et al., 2002; Poling, 1993). Optimum fruit production in the fall-planted annual hill system requires balanced vegetative and reproductive growth. The principle environmental factors that condition physiological response in strawberries are growing temperature, photoperiod, and chilling (Galletta and Bringhurst, 1990). High tunnels can effectively manipulate temperature; however, chilling and photoperiod need to be manipulated in other ways such as selecting the proper nursery plant type and optimizing the planting date (Albregts and Chandler, 1994; Maurer and Umeda, 1999). Long days favor vegetative growth (crowns and runners), whereas short days favor reproductive (flower initiation) development (Galletta and Bringhurst, 1990). Ideally, plants will partition most of the energy to crown production in the fall and to fruit development the next spring. Runner production competes with crown growth and fruit development. Planting too early results in excessive runnering, whereas late planting results in inadequate plant establishment and crown formation. Fall planting dates for annual hill production have been optimized for production areas in Florida, California (Galletta and Bringhurst, 1990), and the midAtlantic region (Poling, 1993). However, developing annual hill systems for other growing systems and environments requires planting date optimization.

The cost of constructing a high tunnel may justify the use of more intensive growing systems. For strawberry production in greenhouses, suspended containers and soilless media are often justified by the higher cost of maintaining greenhouse space (Takeda, 1999). Suspended systems offer means of maximizing the use of available sunlight, thereby increasing yields per production area. This study compared vertical and in-ground high tunnel strawberry production when planting date was optimized for each system. The objective was to develop methods for farmers to maximize yields of top-quality strawberries that could be sold for a premium price at local markets.

\section{Materials and Methods}

Experiments were conducted at the Utah State University Greenville Research Farm in North Logan (lat. 41.766 N, elev. 1405 m, 119 freeze-free days). The soil is a Millville silt loam (coarse-silty, carbonatic, mesic Typic Haploxerolls). High tunnels used for this experiment were constructed of a framework of polyvinyl chloride (PVC) pipe according to Black et al. (2008) and measured $4.3 \mathrm{~m}$ wide $\times 12.8 \mathrm{~m}$ long with an east-west orientation. 
In-ground high tunnel system. The inground system was managed as annual hill culture patterned after the method for producing field strawberries in California and Florida but adapted to colder climates (Black et al., 2002; Poling, 1993). 'Chandler' plug plants were planted into a raised bed $60 \mathrm{~cm}$ wide and $20 \mathrm{~cm}$ high, covered with dark plastic mulch, with beds spaced on 1.2-m centers. Plants were spaced in offset double rows on the beds with $30 \mathrm{~cm}$ between rows and $23 \mathrm{~cm}$ within rows for a total plant density of 7.2 plants $/ \mathrm{m}^{2}$. The experimental plot consisted of two beds that were each $8.2 \mathrm{~m}$ long occupying one portion of one tunnel.

For the 2008 fruiting season, each row was divided into nine six-plant plots with 23$\mathrm{cm}$ spacing between plots, providing a total plot length of $0.9 \mathrm{~m}$. Plots were assigned to one of six planting date treatments and three replicates in a randomized block design with blocking by east to west location in the tunnel. The six planting date treatments represented 2-week intervals from $7 \mathrm{Aug}$. to 16 Oct. 2007. Results from the 2008 growing season indicated that there was a slight difference between the north and south row, likely resulting from proximity to the edge of the tunnel. As a result, the experiment was modified for the 2009 season to have four blocks with blocking to account for this variation (two per row). The additional replication required that the space between plots be decreased and that the latest planting date be omitted. Thus, for the 2009 fruiting season, each bed was divided into 10 sixplant plots with a $10-\mathrm{cm}$ space between plots for a $0.76-\mathrm{m}$ plot length. The five planting dates represented 2-week intervals from 31 July to 25 Sept. 2008 (Table 1).

Vertical production systems. The vertical growing systems were designed to maximize a high-tunnel growing area and were constructed by fastening PVC rain gutters to wooden support towers. The gutters measured $10 \mathrm{~cm}$ across and $8 \mathrm{~cm}$ deep. The bottom gutter was placed $\approx 10 \mathrm{~cm}$ aboveground level. Gutters were spaced $23 \mathrm{~cm}$ apart vertically with a horizontal offset of $12 \mathrm{~cm}$ resulting in a sloped configuration. Two different tower orientations were evaluated for their effect on light interception and consequently yield. The first was a two-sided structure facing east and west, and the second tower system was single-sided and faced south. When maintenance space was considered, the east-west-facing vertical system

Table 1. Planting dates for June-bearing 'Chandler' strawberry plants in each year of the experiment, including daylength at the time of planting.

\begin{tabular}{|c|c|c|c|c|}
\hline \multirow[b]{2}{*}{ Treatment } & \multicolumn{2}{|c|}{2007} & \multicolumn{2}{|c|}{2008} \\
\hline & Date & Daylength (h) & Date & Daylength (h) \\
\hline 1 & 7 Aug. & 14.2 & 31 July & 14.4 \\
\hline 2 & 21 Aug. & 13.6 & 14 Aug. & 13.9 \\
\hline 3 & 4 Sept. & 13.0 & 28 Aug. & 13.3 \\
\hline 4 & 18 Sept. & 12.4 & 11 Sept. & 12.7 \\
\hline 5 & 2 Oct. & 11.7 & 25 Sept. & 12.0 \\
\hline 6 & 16 Oct. & 11.1 & 9 Oct $^{z}$ & 11.4 \\
\hline
\end{tabular}

${ }^{\mathrm{z}}$ Omitted from in-ground system as a result of space constraints.

had a total plant density of 21.5 plants $/ \mathrm{m}^{2}$ and the south-facing vertical system had a total plant density of 16.1 plants $/ \mathrm{m}^{2}$ compared with the in-ground system that had 7.2 plants $/ \mathrm{m}^{2}$.

The east-west-facing vertical system consisted of two towers that were $1 \mathrm{~m}$ tall and contained five 2.4-m-long gutter rows on each side of the towers for a total of 10 gutter rows per tower. The gutters were filled with soilless media, a 1:1:1 peat:perlite:vermiculite mix supplemented with dolomite $\left(2 \mathrm{~kg} \cdot \mathrm{m}^{3}\right)$ before planting 4-week-old 'Chandler' plug plants. Each gutter row was divided into two plots $1.2 \mathrm{~m}$ long, and each plot was planted with five plug plants at $23-\mathrm{cm}$ spacing. Gutter plots were assigned to one of six blocks and randomly assigned to one of six planting dates (Table 1). Two plots on each tower were not used in the experiment, thus making a total of 36 usable plots in the east-west-facing system. Within each eastwest-facing tower, three adjacent gutters, or six adjacent plots, were considered to be a block with six different planting dates randomly assigned to plots within the block. Planting dates were the same as those used for the in-ground system with the exception of an additional planting date of 9 Oct. for the second year. The experimental layout of this vertical system allowed for analyzing results according to two different designs. First, the data could be analyzed as a randomized block design with six planting date treatments and six blocks, in which blocks accounted for differences in distance from the ground and east or west exposure. Second, the results could be analyzed as a split-plot design with two replications, in which main plot treatment was tower position and subplot treatment was planting date. The blocks remained the same for both growing seasons with planting date treatments rerandomized for each season.

The south-facing vertical system consisted of two towers that were $1.5 \mathrm{~m}$ tall, and each contained seven south-facing gutters. Each gutter was $3.1 \mathrm{~m}$ in length and was divided into two $1.5-\mathrm{m}$ long sections. Each gutter section was considered a plot and contained six plants spaced $23 \mathrm{~cm}$ apart. The top gutter on each of the towers was not used in the experiment, thus making a total of 12 plots on each tower for a total of 24 usable plots in the south-facing system. Within each south-facing tower, three adjacent gutters, or six adjacent plots, were considered to be a block with six different

HortScience Vol. 45(10) October 2010 planting dates (Table 1) randomly assigned to each plot within the block. Thus, the southfacing vertical system contained a total of four blocks that accounted for distance from the ground. Blocks remained the same for both growing seasons, and planting dates were rerandomized for each season.

Field planting. An outside field site was planted in a manner similar to the high-tunnel in-ground annual hill system described previously. Three replicate blocks were planted with each of the six planting dates for 2009 production. The purpose of the outside field comparison was to optimize planting date and to determine how much the fruiting season was advanced by high tunnels. Early yield, a key factor in the analysis of the hightunnel growing systems, was considered to be all yield produced before there was significant outdoor production.

Plug plant production. Plug plants were produced as described by Rowley et al. (2010). Briefly, mother plants were obtained from a commercial nursery and established in media-filled PVC gutters in a greenhouse maintained at $24^{\circ} / 18{ }^{\circ} \mathrm{C}$ day/night temperature with supplemental lighting to ensure a greater than 16 -h photoperiod. Runner tips were collected $\approx 30 \mathrm{~d}$ before the scheduled tunnel planting date and planted in 50-cell plug trays $\left(\approx 115 \mathrm{~cm}^{3}\right.$ per plug $)$ containing soilless planting media described previously. Runner tips were maintained in a greenhouse under intermittent mist for $20 \mathrm{~d}$ and then removed from intermittent mist for another 10 d before planting (Durner et al., 2002; Hokanson et al., 2004; Takeda and Newell, 2006). During the last $10 \mathrm{~d}$, a 20-20-20 water soluble fertilizer mix was applied at $100 \mathrm{ppm}$ nitrogen at each irrigation.

Data collection and analysis. Throughout the fall and spring growing seasons, runners were counted and removed on a weekly basis. Branch crowns were counted on a monthly basis, and ripe fruit was harvested twice weekly during the production season. Total mass of ripe fruit was determined for individual plots, and average fruit size was determined on a 10 -fruit sample. Data were analyzed using the PROC GLM procedure of the SAS statistical analysis software (SAS Institute, Cary, NC) with statistical significance of $P=0.05$. The planting date effect in each growing system was analyzed independent of the other growing systems as a randomized complete block design with one treatment factor. Trend analysis was carried out using orthogonal contrasts and curves fitted based on the significance of the linear and quadratic contrasts. Curve fitting was done in Microsoft Excel (Microsoft Corp., Redmond, WA) or SigmaPlot (Systat Software Inc., San Jose, CA) and optimum planting date determined based on the fitted curve equation.

\section{Results and Discussion}

First harvests for the in-ground high tunnel system were 5 May 2008 and 7 May 2009 with peak production occurring around the end of May for both years. The first 
harvests for the vertical growing systems were $\approx 2$ weeks later than for the in-ground system, or 22 May 2008 and 18 May 2009, with peak production occurring around the first week in June. Production from all systems ended approximately the first of July. By comparison, the first harvest for the outdoor field planting in 2009 was 4 June with peak production during the third and fourth weeks of June, also ending during the first week in July. These results indicate that high tunnels advanced June-bearing strawberry production by 4 to 5 weeks. Thus, early yield in the high-tunnel treatments was defined as the first 5 weeks of harvest.

In-ground high tunnel system. Fall runner growth and branch crown development are important indications of optimal planting date. Fall runner production was highest in the earliest planting dates for both seasons (Fig. 1), decreasing with later planting dates, with no significant runner production for planting dates after $28 \mathrm{Aug}$. Crown numbers in both 2008 and 2009 were positively correlated with early yields (Fig. 1) and followed a quadratic planting date response with fewer crowns at the earliest and latest planting dates. Predicted optimum planting dates were
3 Sept. 2007 and 25 Aug. 2008. Thus, the later plantings effectively focused growth on crown formation instead of runners that would need to be removed (Galletta and Bringhurst, 1990).

Spring runner production may also indicate optimal planting date. Plants that were established too late were too small for adequate flower bud initiation and cropping. In the absence of developing fruit, more energy was devoted to vegetative growth in the form of runners. This can be seen in Figure 1 in which the smaller plants (lower crown number) tended to produce more spring runners and less fruit. Spring runner production for both years increased after the third planting date (4 Sept. 2007 and 28 Aug. 2008).

For the 2008 fruiting season, highest early and total yields were obtained when strawberries were planted on 4 Sept. Early yields for this planting date treatment were $478 \mathrm{~g} /$ plant (Fig. 1), which consisted of $65 \%$ of the total yield (Table 2). For the 2009 harvest season, the 28 Aug. planting date treatment resulted in the highest early yields, $329 \mathrm{~g} /$ plant or $62 \%$ of the total yield. Trend analysis of early yields from both 2008 and 2009 showed significant quadratic relationships

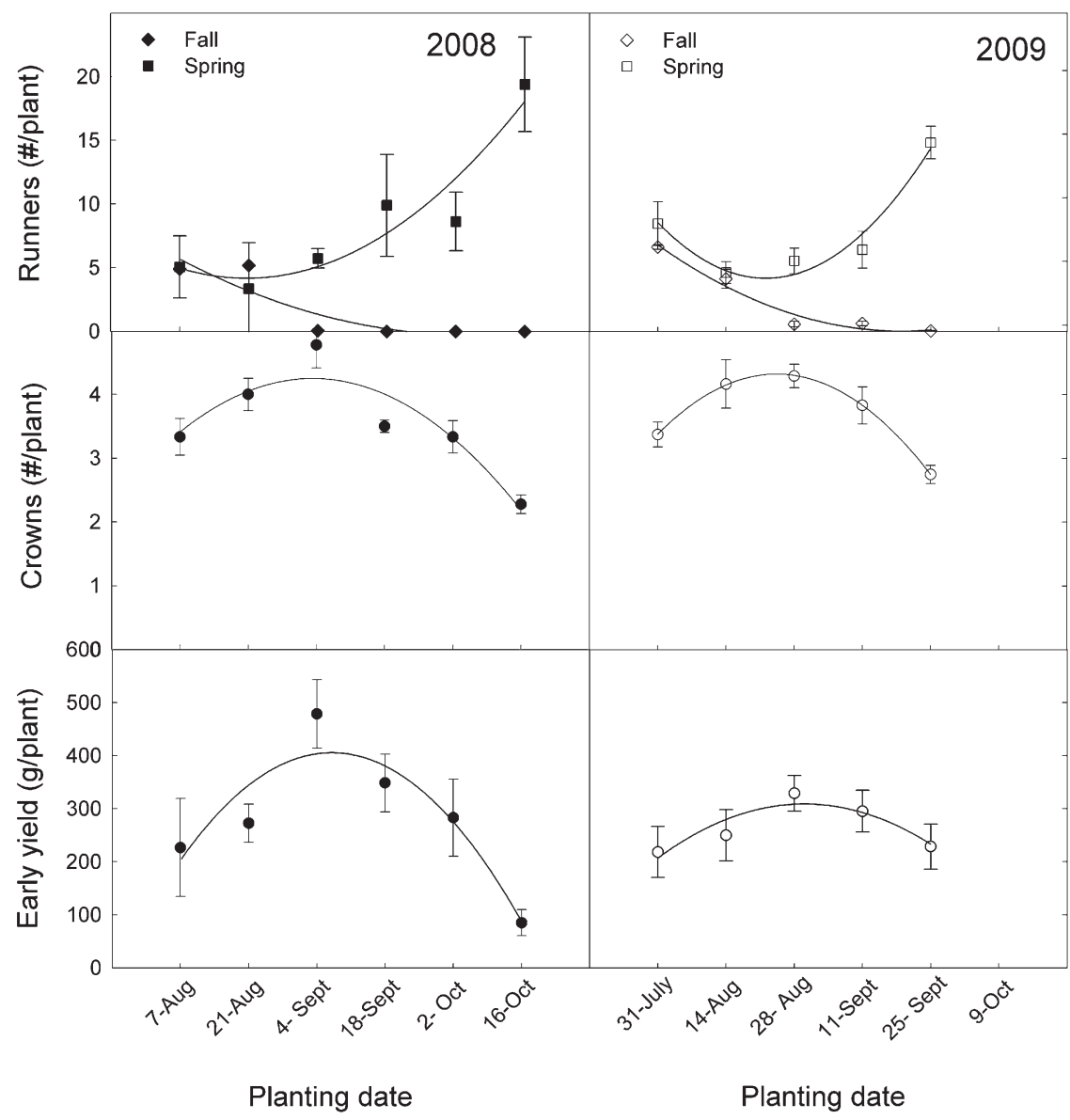

Fig. 1. The effect of fall planting date on runner production, branch crown formation, and early yields for the in-ground tunnel system. Early yields were the first 5 weeks of harvest for both years and corresponded with production before the beginning of the field season. Crown number per plant is reported for the beginning of the harvest season. Fall runners are those produced between planting and 31 Dec. and spring runners are those produced between 1 Jan. and the end of harvest. Values are the means and SE of three replicate plots. with predicted optimal planting dates of 7 Sept. 2007 and 30 Aug. 2008. Later plantings in both years had higher early yields as a percent of total yield. However, this percent was the result of a sharp reduction in total yields (Table 2).

The predicted optimal planting dates for total yield were 30 Aug. 2007 and 29 Aug. 2008. Although total yields may be of some interest, the main objective of high tunnels is early yields, which occur before significant outdoor production. Taken together, results for runner growth, crown formation, and early yield over both years indicate that the optimum planting date for the in-ground high tunnel system at this location was between 25 Aug. and 7 Sept., or $\approx 1$ Sept. which has a daylength of $13.1 \mathrm{~h}$. Optimum planting date would be expected to differ for other cultivars and other locations.

Vertical systems. Both vertical systems failed to produce economic yields in the 2008 season (Table 3), likely the result of winter injury to roots and crowns. During the winter months, gutters remained attached to the vertical support system and were covered with a floating row cover. Thermocouples placed in the root zone of both the in-ground and vertical tunnel systems were attached to a data logger recording temperature at hourly intervals. The extreme high and low root zone temperatures for the vertical system were $21{ }^{\circ} \mathrm{C}$ (14 Jan.) and $-10{ }^{\circ} \mathrm{C}(2 \mathrm{Jan}$.) compared with $5{ }^{\circ} \mathrm{C}(26 \mathrm{Jan}$.$) and 2{ }^{\circ} \mathrm{C}(2$ Jan.) for the in-ground system. These extreme root zone temperature fluctuations were the likely cause of visible plant injury evident in damaged leaves and crowns. Visibly damaged plants showed limited productivity and were more prone to fungal diseases, including increased fruit rot. As a result, maximum early yield was 33 and $38 \mathrm{~g} /$ plant for the east-west-facing and the south-facing vertical system, respectively (Table 3 ) compared with $478 \mathrm{~g} /$ plant for the optimum planting date for the in-ground tunnel system (Fig. 1). Plant growth data for the vertical growing systems show that later planting dates had fewer crowns and fall runners (data not shown). Spring runner numbers averaged more than seven runners per plant (see Rowley, 2010) and did not differ significantly among planting dates. This high number of spring runners would be expected for such a light crop load.

In preparation for the 2009 fruiting season, gutters were removed from the vertical support system during the winter of 2008 2009 , placed on the ground inside the tunnel, and covered with floating row cover. Significant improvements in winter survival and yields in the second year were attributed to this change in winter management. For the east-west system, greatest early yields were produced between 14 Aug. and 11 Sept. planting dates with mean production of 136 $\mathrm{g} /$ plant. Trend analysis of early and total yields showed significant quadratic trends with predicted maximum on 5 Sept. and 3 Sept., respectively (Table 4). Based on early yields, total yields, and runner production 
(data not shown), the optimal planting date for the east-west-facing vertical system is between 25 Aug. and 7 Sept. or 1 Sept. \pm 7 d.

For the south-facing vertical system in 2009, there were no significant planting date differences for either early or total yields $(P=0.9$; Table 4). Lack of significant treatment differences in yield make it difficult to determine an optimal planting date. Fall runner numbers dropped to less than 0.2 by the 11 Sept. planting date, and crown numbers decreased linearly with planting date (data not shown), suggesting that the optimum planting date for this system was also in early September.

Gutter position on the towers had a signifbut not the south-facing system in both years (Tables 3 and 4). Plants near the top of the towers had higher production, likely as a result of increased light compared with the lower positions where there was more morning and afternoon shading. icant effect on yields for the east-west-facing

Field annual hill system. Fall runner production decreased linearly with later planting dates with no significant runner production in the 11 Sept. and later treatments. Crown numbers were not significantly different among the first four planting dates but were significantly lower $(P=0.01)$ for the last two planting dates (Table 5). Total yields showed no significant differences among the first four planting dates but decreased significantly $(P<0.02)$ with the last two planting dates. It appears that planting after 25 Sept. did not allow sufficient vegetative and crown growth to support a large berry crop the next spring, whereas total yields for planting dates before 11 Sept. are not significantly different from earlier dates. This suggests that the optimal planting date for field-grown 'Chandler' strawberries in northern Utah is before the middle of September.

System comparison. The research reported here was set up as four separate replicated

Table 2. The effect of fall planting date on early and total yields for the in-ground tunnel system. ${ }^{\mathrm{z}}$

\begin{tabular}{|c|c|c|c|c|c|c|}
\hline \multirow[b]{2}{*}{ Treatment } & \multicolumn{3}{|c|}{2008} & \multicolumn{3}{|c|}{2009} \\
\hline & Date & $\begin{array}{l}\text { Early yield } \\
(\% \text { of total) }\end{array}$ & $\begin{array}{c}\text { Total yield } \\
\text { (g/plant) }\end{array}$ & Date & $\begin{array}{l}\text { Early yield } \\
(\% \text { of total) }\end{array}$ & $\begin{array}{c}\text { Total yield } \\
\text { (g/plant) }\end{array}$ \\
\hline$\overline{1}$ & 7 Aug. & $43 \%$ & $530 \pm 50$ & 31 July & $68 \%$ & $321 \pm 21$ \\
\hline 2 & 21 Aug. & $40 \%$ & $681 \pm 26$ & 14 Aug. & $58 \%$ & $434 \pm 50$ \\
\hline 3 & 4 Sept. & $65 \%$ & $735 \pm 53$ & 28 Aug. & $62 \%$ & $530 \pm 28$ \\
\hline 4 & 18 Sept. & $65 \%$ & $537 \pm 18$ & 11 Sept. & $64 \%$ & $463 \pm 38$ \\
\hline 5 & 2 Oct. & $71 \%$ & $400 \pm 38$ & 25 Sept. & $68 \%$ & $334 \pm 53$ \\
\hline 6 & 16 Oct. & $73 \%$ & $116 \pm 37$ & & & \\
\hline
\end{tabular}

Analysis of variance

\begin{tabular}{lcc} 
Factor & & $P$ value \\
Planting date & $<0.001$ & 0.006 \\
Linear & $<0.001$ & 0.69 \\
Quadratic & $<0.001$ & $<0.001$ \\
Optimum $^{y}$ & 30 Aug. & 29 Aug. \\
\hline
\end{tabular}

${ }^{2}$ Values are reported as numbers per plant with SES for three replications in 2008 and four replications in 2009. Early yields are from 5 May to 5 June 2008 and 7 May to 8 June 2009.

${ }^{\mathrm{y}}$ Optimum predicted from fitted quadratic curve. experiments to optimize planting date for each production system. With the exception of the field study, the planting dates were repeated over 2 years. The production systems were not replicated and therefore cannot be compared statistically. However, qualitative comparisons of systems for production season and economics are instructive. To optimize planting dates within systems, yields were calculated on a per-plant basis. Because planting density differed among treatments, yield values per unit area were calculated. Based on the tunnel layout used for these studies, and including maintenance areas, the planting densities for the in-ground, east-west- and south-facing systems were 7.2, 21.5, and 16.1 plants $/ \mathrm{m}^{2}$, respectively. Plant density for the annual hill field comparison was 5.8 plants/ $\mathrm{m}^{2}$, where the difference between the field system and the in-ground tunnel system was the result of increased distance between beds.

From the 2009 data, a yield time course was prepared to compare production seasons among systems based on the optimum planting date for each system (Fig. 2). For the inground tunnel system and the south-facing vertical system, the optimal planting date was determined by the greatest early yield. In the east-west-facing vertical system, greatest early yield was essentially equal for three planting dates. Therefore, total yield was used to select among these three planting dates. The optimal planting date for the field comparison was also determined by total yield. Based on these criteria, the 28 Aug., 28 Aug., 25 Sept., and 11 Sept. planting dates were used for the in-ground, east-west vertical, south vertical, and the field systems, respectively. On a per-plant basis, the in-ground system had the highest early (329 g/plant) and total $(530 \mathrm{~g} /$ plant $)$ yield. The south-facing vertical system was next with an early yield of 164

Table 3. The effect of Fall 2007 planting date on early and total yields for the east-west and south-facing vertical systems in $2008 .^{z}$

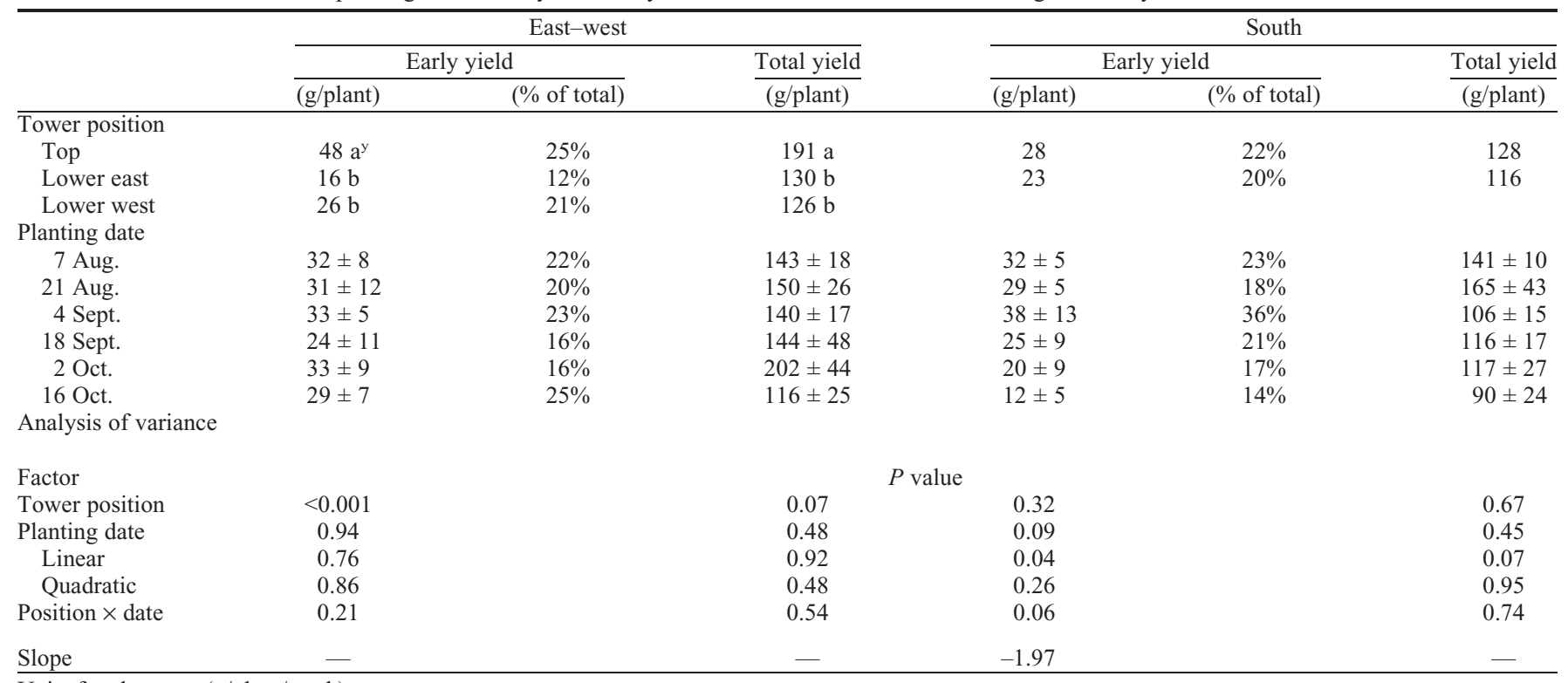

Units for slope are (g/plant/week).

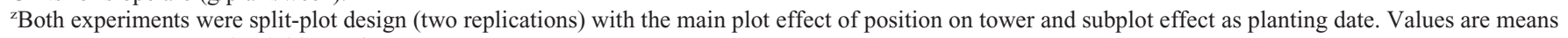
per plant with SEs. Early yields are from 5 May to 5 June 2008 .

${ }^{\mathrm{y}}$ Means followed by the same letter are not significantly different at $\alpha=0.05$. Means separation was with the pdiff option in SAS. 
Table 4. The effect of Fall 2008 planting date on 2009 early and total yields for the east-west and south-facing vertical systems. ${ }^{z}$

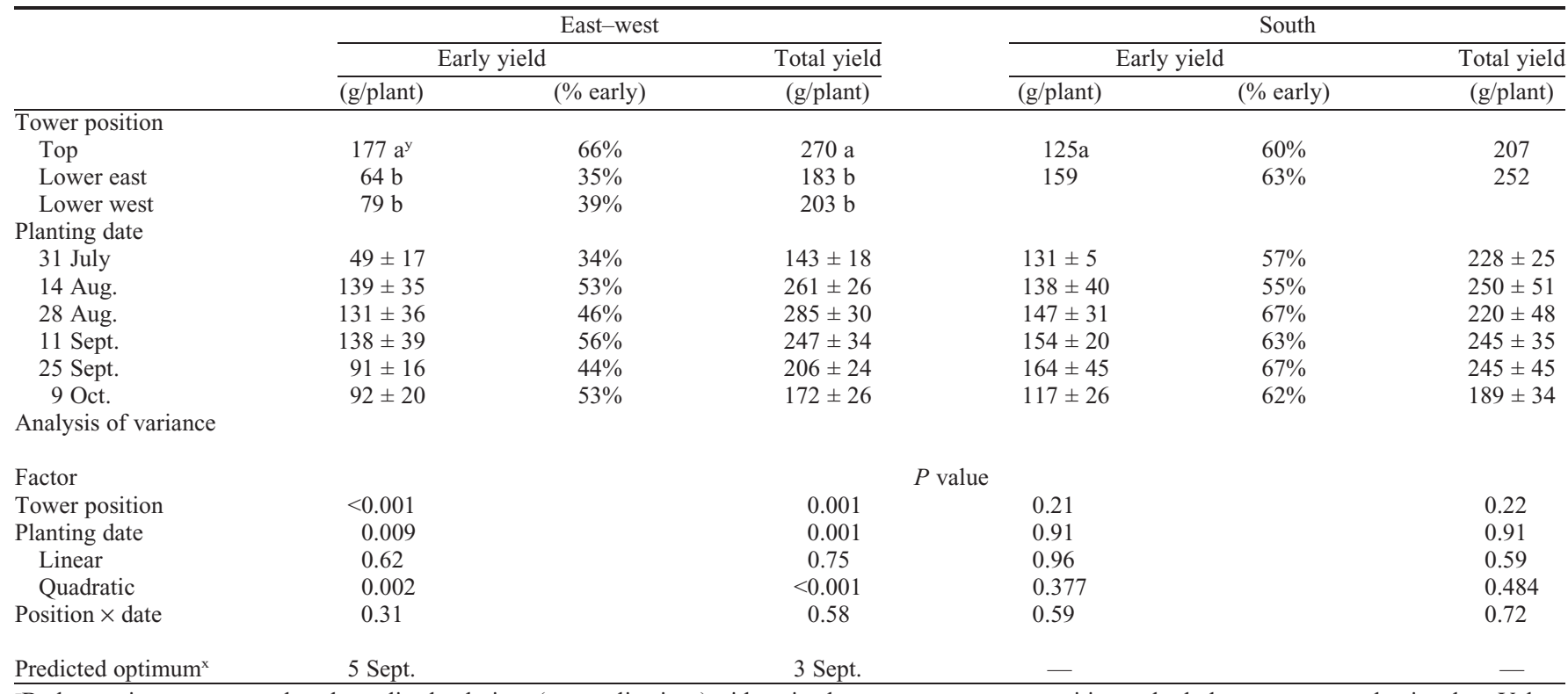

${ }^{2}$ Both experiments were analyzed as split-plot designs (two replications) with main plot treatment as tower position and subplot treatment as planting date. Values are means and SES in grams per plant. Early yields are from 7 May to 8 June2009.

${ }^{y}$ Means followed by the same letter are not significantly different at $\alpha=0.05$. Means separation was with the pdiff option in SAS.

${ }^{\mathrm{x}}$ Optimum predicted from fitted quadratic curve.

Table 5. The effect of Fall 2008 planting date on runner and crown number and yield for field-grown strawberries. ${ }^{z}$

\begin{tabular}{lccc}
\hline Planting date & $\begin{array}{c}\text { Fall runners } \\
\text { (no./plant) }\end{array}$ & $\begin{array}{c}\text { Crowns } \\
\text { (no./plant) }\end{array}$ & $\begin{array}{c}\text { Total yield } \\
\text { (g/plant) }\end{array}$ \\
\hline 31 July & $3.56 \pm 1.27$ & $4.69 \pm 1.92$ & $220 \pm 69$ \\
14 Aug. & $4.82 \pm 0.49$ & $4.10 \pm 0.38$ & $277 \pm 87$ \\
28 Aug. & $2.00 \pm 0.29$ & $3.73 \pm 0.07$ & $232 \pm 36$ \\
11 Sept. & $0.39 \pm 0.31$ & $3.64 \pm 0.34$ & $317 \pm 91$ \\
25 Sept. & $0.00 \pm 0.00$ & $1.38 \pm 0.66$ & $95 \pm 44$ \\
9 Oct. & $0.00 \pm 0.00$ & $1.45 \pm 0.23$ & $84 \pm 50$ \\
Analysis of variance & & & \\
Factor & & $P$ value & 0.17 \\
Planting date & $<0.001$ & 0.12 & 0.07 \\
$\quad$ Linear & $<0.001$ & 0.010 & 0.13 \\
$\quad$ Quadratic & 0.51 & 0.63 & - \\
Slope (no./plant/week) & & & -0.35 \\
\hline
\end{tabular}

${ }^{\mathrm{z}}$ Fall runners are those produced between planting and $31 \mathrm{Dec} 2008$. Crown numbers were counted at the beginning of harvest on $27 \mathrm{Apr} 1009$. Values are means and ses for three replicate six-plant plots.

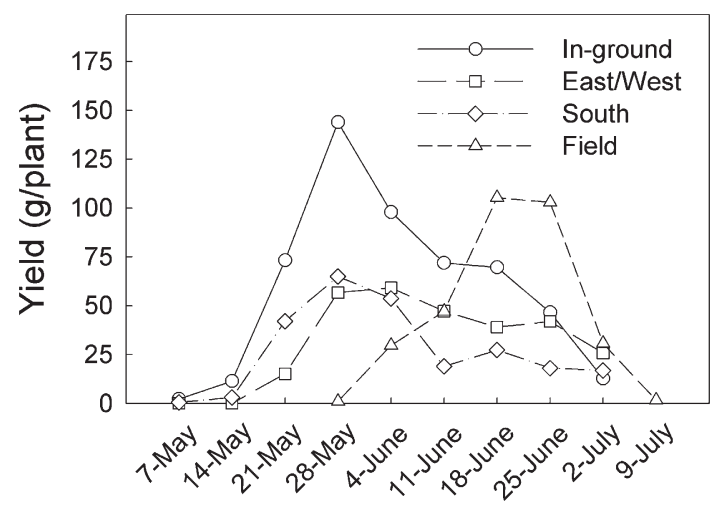

Fig. 2. Harvest time course for the four production systems during the 2009 season. Planting date treatments of 28 Aug., 28 Aug., 25 Sept., and 11 Sept. were used for the in-ground, east-west vertical, south-facing vertical, and field growing systems, respectively. No statistical comparison among treatments is valid, because the production systems were not replicated. The time course is shown here only to give an indication of relative harvest season. $\mathrm{g} /$ plant and a total yield of $245 \mathrm{~g} / \mathrm{plant}$. The east-west-facing vertical system had the lowest early yield ( $131 \mathrm{~g} /$ plant) but higher total yield (285 g/plant). However, the higher plant density of the east-west system maximized early yields at $2.82 \mathrm{~kg} \cdot \mathrm{m}^{-2}$ compared with 2.64 and $2.37 \mathrm{~kg} \cdot \mathrm{m}^{-2}$ for the south-facing vertical and the in-ground systems, respectively.

Yield for the field system was $317 \mathrm{~g} / \mathrm{plant}$, or $1.84 \mathrm{~kg} \cdot \mathrm{m}^{-2}$ at a plant density of 5.8 plants $/ \mathrm{m}^{2}$ (offset double rows with $23 \mathrm{~cm}$ in-row spacing and beds on 1.5-m centers). Using a similar system in North Carolina, Poling (1993) reported yields of 1.7 to $1.8 \mathrm{~kg} \cdot \mathrm{m}^{-2}$, whereas Black et al. (2002) reported yields of $1.83 \mathrm{~kg} \cdot \mathrm{m}^{-2}$. Therefore, high tunnels were very effective in increasing yields and the east-west-facing vertical system maximized yield per tunnel area. Because the 12.8-m long tunnels used for this study were scaled for research purposes, a more common commercial scale would be $29.3 \mathrm{~m}$. In a $4.3 \mathrm{~m} \times$ 29.3-m high tunnel, the east-west-facing vertical system would be expected to produce $56.7 \mathrm{~kg}$ more early yield than the in-ground system. Assuming a 454-g clamshell is sold for $\$ 4.00$, this increases a producer's gross income by $\approx \$ 500$ per season. However, this increase in yield per tunnel area comes with substantial additional costs. Compared with the in-ground tunnel system, some of the added expenses include building the vertical growing system, purchasing or producing additional plug plants, purchasing soilless planting media, and disassembling and reassembling towers for winter protection. The partial budget shown in Table 6 gives a more detailed breakdown of the additional costs and revenues associated with the east-westfacing vertical system. The total cost of constructing the gutter system, including supplies and labor, was based on constructing 
Table 6. Partial budgets comparing the in-ground tunnel system to field production for a low-cost high tunnel $(4.3 \mathrm{~m} \times 29.3 \mathrm{~m})$ or equivalent production area and the east-west-facing vertical system to the in-ground tunnel system for a low-cost tunnel. ${ }^{\mathrm{z}}$

\begin{tabular}{|c|c|c|c|c|}
\hline & \multicolumn{4}{|c|}{ Comparison } \\
\hline & \multicolumn{2}{|c|}{ In-ground-field } & \multicolumn{2}{|c|}{ East-west vertical-in-ground } \\
\hline \multicolumn{5}{|l|}{ Additional revenue } \\
\hline Sales & $\$$ & 2,770 & $\$$ & 500 \\
\hline \multicolumn{5}{|l|}{ Additional expenses } \\
\hline Management labor & $\$$ & 420 & $\$$ & 100 \\
\hline Harvest (labor and containers) & $\$$ & 451 & $\$$ & 100 \\
\hline Form raised beds & & & $\$$ & $(210)$ \\
\hline Soilless planting media & & & $\$$ & 320 \\
\hline Plug plants & & & $\$$ & 500 \\
\hline Total additional expenses & $\$$ & 871 & $\$$ & 810 \\
\hline Yearly operating profit (loss) & $\$$ & 1,899 & $\$$ & $(310)$ \\
\hline Annual depreciation & $\$$ & 241 & $\$$ & 283 \\
\hline Net income (loss) & $\$$ & 1,658 & $\$$ & $(593)$ \\
\hline Depreciation calculations & \multicolumn{2}{|c|}{ Tunnel } & \multicolumn{2}{|c|}{ Vertical system } \\
\hline \multirow[t]{2}{*}{ Useful life (years) } & Tunnel & 6 & & 6 \\
\hline & Plastic & 3 & & \\
\hline Initial cost & $\$$ & 1,447 & $\$$ & 1,700 \\
\hline Annual depreciation & $\$$ & 241 & $\$$ & 283 \\
\hline
\end{tabular}

zThe complete budgets are published elsewhere (Rowley, 2010).

a similar system for this experiment and was estimated to be $\$ 13.50 / \mathrm{m}^{2}$, or $\approx \$ 1700$ for a $4.3 \times 29.3-\mathrm{m}$ low-cost high tunnel. Assuming a 6-year useful life, the annual cost or depreciation expense associated with this system is $\$ 283$. Operating losses of $\$ 310$ per year combined with the annual depreciation expense result in a net loss of $\$ 593$ per year for the east-west-facing vertical system compared with the high-tunnel in-ground system. In climates with milder midwinter temperatures where root injury would be less likely, this vertical growing system could potentially prove to be more profitable.

Fruit pricing depends on local markets and marketing strategies. It has been suggested that out-of-season fruit can command a price premium of double the regular in-season price for local produce (Koester and Pritts, 2003). Fruit produced in this study was sold through an oncampus retail shop and at a local farmers market in 454-g clamshells. Even with California fruit available through the grocery stores at much lower prices, we found little difficulty in selling in-season fruit for $\$ 6.62 / \mathrm{kg}$ and early fruit for $\$ 9.92 / \mathrm{kg}$, or a $50 \%$ price premium.

With the increased total yields, and with the early yields sold at a $50 \%$ price premium, a 4.3 $\mathrm{m} \times 29.3-\mathrm{m}$ high tunnel using the in-ground production system would generate an additional $\$ 2770$ in revenue compared with field production (Table 6). After accounting for the additional costs of building and managing the high tunnel, and the additional cost of harvesting the fruit, this would result in increased net income of $\$ 1658$ for a $4.3 \mathrm{~m} \times 29.3-\mathrm{m}$ area or $\$ 13.16 / \mathrm{m}^{2}$. These results indicate that high tunnels can effectively and economically be used in the Intermountain West as an earlyseason extension technique for strawberries.

Fall planting dates for the in-ground tunnel and the east-west-facing vertical systems were optimized for northern Utah conditions. Two consecutive years of data indicate that the optimal fall planting date for early yields in the in-ground tunnel system is $\approx 1$ Sept. One year of meaningful data collected from the east-west-facing vertical system also indicates the optimal planting date was $\approx 1$ Sept. Strawberries grown in high tunnels began production $\approx 4$ to 5 weeks before outdoor production with higher total seasonal production. Both out-of-season yields and greater total seasonal production contributed to the economic benefits of the tunnel system. Whereas the east-west-facing vertical system was shown to maximize yield per area, the yield benefits were not sufficient to offset the additional production costs of the vertical system.

\section{Literature Cited}

Albregts, E.E. and C.K. Chandler. 1994. Effect of transplant chilling and planting date on fruiting response of 4 strawberry clones. Proc. Fla. State Hort. Soc. 107:323-325.

Black, B., D. Drost, D. Rowley, and R. Heflebower 2008. Construction a low-cost high tunnel. Utah State University Extension bulletin \# HG/High Tunnels/2008-01pr, Utah State University, Logan, UT. 13 Sept. 2010. <http://extension.usu. edu/publications $>$.

Black, B.L., J.M. Enns, and S.C. Hokanson. 2002. A comparison of temperate-climate strawberry production systems using eastern genotypes. HortTechnology 12:670-675.
Demchak, K. 2009. Small fruit production in high tunnels. HortTechnology 19:44-49.

Demchak, K., W.J. Lamont, and M.D. Orzalek. 2006. High tunnel bramble and strawberry culture, high tunnel production manual. Penn State University, State College, PA.

Durner, E.F., E.B. Poling, and J.L. Maas. 2002. Recent advances in strawberry plug transplant technology. HortTechnology 12:545-550.

Galletta, G.J. and R.S. Bringhurst. 1990. Strawberry management, p. 83-156. In: Galletta, G.J. and D.G. Himelrick (eds.). Small fruit crop management. Prentice-Hall, Englewood Cliffs, NJ.

Hokanson, S.C., F. Takeda, J.M. Enns, and B.L. Black. 2004. Influence of plant storage duration on strawberry runner tip viability and field performance. HortScience 39:1596-1600.

Koester, K. and M. Pritts. 2003. Greenhouse raspberry production guide. Cornell University, Ithaca, NY. 13 Sept. 2010. <http://www. fruit.cornell.edu/Berries/ghrasp.pdf>.

Maurer, M.A. and K. Umeda. 1999. Influence of planting date on strawberry growth and development in the low desert. HortScience 34: 474.

Moller, A.L. and R.R. Gillies. 2008. Utah climate Utah State University, Logan, UT.

Orzolek, M., W. Lamont, and E. Burkhart. 2006. High tunnel vegetable crop production, $\mathrm{p}$. 117-125. High tunnel production manual. 2nd ed. Pennsylvania State University, University Park, PA.

Poling, E.B. 1993. Strawberry plasticulture in North Carolina: II. Preplant, planting, and postplant considerations for growing 'Chandler' strawberry on black plastic mulch. HortTechnology 3:383-393.

Pollack, S. and A. Perez. 2008. Fruit and tree nuts situation and outlook yearbook 2008. U.S Dept. Agr. 13 Sept. 2010. <http://www.ers.usda. gov/Publications/fts/Yearbook08/FTS2008.pdf $>$.

Rasmussen, C. and L. White. 2006. High tunnel cut flower production, p. 135-149. High tunnel production manual. 2nd ed. Pennsylvania State University, University Park, PA.

Rowley, D. 2010. Season extension of strawberry and raspberry production using high tunnels. MS thesis, Utah State University, 13 Sept. 2010. $<$ http://digitalcommons.usu.edu/etd/716/>.

Rowley, D., B. Black, and D. Drost. 2010. Strawberry plug plant production. Utah State University Extension bulletin \# Horticulture/High Tunnels/2010-02pr, Utah State University, Logan, UT. 13 Sept. 2010. <http://extension.usu. edu/publications $>$.

Sjulin, T.M. 2003. The North American small fruit industry 1903-2003. II. Contributions of public and private research in the past 25 years and a view to the future. HortScience 38:960 967.

Takeda, F. 1999. Out-of-season greenhouse strawberry production in soilless substrate. Adv. Strawberry Res. 18:4-11.

Takeda, F. and M. Newell. 2006. Effects of runner tip size and plugging date on fall flowering in short-day strawberry (Fragaria Xananassa Duch.) cultivars. Intl. J. Fruit Sci. 6:103-117. 